\title{
EDUKASI LITERASI KEUANGAN DAN PELATIHAN KOMUNIKASI TERAPEUTIK DI STIK SINT CAROLUS, JAKARTA
}

DOI: https://doi.org/10.33024/jkpm.v4i4.3898

\author{
Francisca Hermawan ${ }^{1}$, Sri Hapsari Wijayanti ${ }^{2 *}$, Siti Saadah ${ }^{3}$, Ambrosius \\ Aprian Tri Putranto ${ }^{4}$
}

Universitas Katolik Indonesia Atma Jaya, Jakarta

Email Korespondensi: sri.hapsari@atmajaya.ac.id

\begin{abstract}
ABSTRAK
Mahasiswa lulusan kebidanan perlu dipersiapkan untuk terjun ke masyarakat dalam berbinis atau berkarier. Kebutuhan akan pemahaman literasi keuangan dan kemampuan berkomunikasi di tempat mereka akan bekerja sangat dibutuhkan. Karena itu kegiatan ini bertujuan mengedukasi literasi keuangan dan memberikan pelatihan komunikasi terapeutik. Target program ini adalah mahasiswa dan dosen STIK Sint Carolus berjumlah dua puluh orang. Melalui metode tutorial dan diskusi, peserta kegiatan ini menyambut baik dan antusias materi yang disajikan karena relevan dengan kebutuhan mereka saat ini dan masa depan. Mahasiswa mempunyai peluang karier yang besar untuk menjadi wirausahawan dalam bidang pengelolaan klinik kebidanan. Begitu pula mereka akan melayani pasien dan bekerja sama dengan sesama bidan atau dokter untuk menjadi bidan yang terampil. Kegiatan ini menunjukkan adanya minat peserta untuk memahami lebih dalam tentang literasi keuangan dan komunikasi terapeutik.
\end{abstract}

Kata Kunci: Literasi Keuangan, Komunikasi Terapeutik, STIK Sint Carolus.

\begin{abstract}
Students are an asset to be prepared to enter the workplace as a businessman or get the high career. The need for an understanding of financial literacy and the ability to communicate in their world of work is urgently needed. Therefore this activity aims to educate financial literacy and provide therapeutic training. The target of this program is twenty students and lecturers of STIK Sint Carolus. Through tutorial and discussion methods, participants in this activity welcomed and were enthusiastic about the material presented because it was relevant to their needs today and in the future. Students have great career opportunities to become entrepreneurs in the management of midwifery clinics. Likewise, they will serve patients and work together with peers or doctors to become professionals. This activity showed the participants' interest in understanding more deeply about financial literacy and therapeutic communication.
\end{abstract}

Keywords: Financial Literacy, Therapeutic Communication, STIK Sint Carolus. 


\section{PENDAHULUAN}

Masyarakat memiliki tanggung jawab untuk mengelola keuangan mereka. Meningkatnya kebutuhan hidup tidak memengaruhi pertumbuhan penghasilan di masa mendatang. Perubahan teknologi yang semakin canggih juga dapat mendorong masyarakat untuk lebih konsumtif. Contoh, dengan adanya e-commerce para penjual beralih ke penjualan online sehingga masyarakat terus melakukan konsumsi secara berlebihan. Inilah mengapa literasi keuangan cukup penting agar masyarakat dapat mempersiapkan kebutuhan keuangan di masa mendatang.

Menurut Stolper dan Walter (2017), rendahnya pengetahuan tentang literasi keuangan akan berdampak terhadap tingkat kerentanan rumah tangga dan juga berpotensi mengalami kerugian di masa depan. Bonus demografi merupakan kondisi yang menunjukkan bahwa suatu negara mendapat keuntungan ekonomis karena didorong oleh tingginya usia produktif di negara tersebut (Maryati, 2015).

Menurut Otoritas Jasa Keuangan, literasi keuangan adalah pengetahuan, keterampilan, dan keyakinan yang memengaruhi sikap dan perilaku untuk meningkatkan kualitas pengambilan keputusan dan pengelolaan keuangan dalam rangka mencapai kesejahteraan. Literasi keuangan juga mampu mengoptimalisasikan uang untuk terus bertambah, seperti melakukan investasi yang memiliki potensi untuk mendapatkan keuntungan dalam jangka panjang. Kesulitan keuangan bukan hanya dari fungsi pendapatan semata, melainkan juga dapat muncul jika terjadi kesalahan dalam pengelolaan keuangan, seperti kesalahan dalam penggunaan kredit dan tidak ada perencanaan keuangan untuk ke depannya. Adanya pengetahuan dan literasi keuangan dapat membantu masyarakat dalam mengatur perencanaan keuangan sehingga masyarakat dapat memaksimalkan nilai waktu uang. Keuntungan yang diperoleh juga akan semakin besar sehingga taraf kehidupan masyarakat meningkat.

Pendidikan pengetahuan keuangan bagi mahasiswa di lingkungan STIK Sint Carolus diperlukan berdasarkan komunikasi dengan pihak institusi. Bagi masyarakat, termasuk mahasiswa, pengetahuan keuangan dapat memberi banyak manfaat, seperti i) dapat memilih dan menggunakan produk dan layanan keuangan sesuai dengan kebutuhan mereka, ii) dapat membuat perencanaan keuangan yang lebih baik, dan iii) menghindari kegiatan investasi pada alat keuangan yang tidak jelas. Program edukasi literasi keuangan ini penting dan relevan karena saat ini pemerintah sedang menggalakkan sumber pembiayaan pembangunan yang bersumber dari pembiayaan dalam negeri melalui penerbitan surat-surat berharga negara yang bisa dijangkau oleh investor individual. Surat-surat berharga negara ini, bagi masyarakat, merupakan instrumen investasi yang risikonya sangat rendah. Pengetahuan masyarakat tentang bentuk-bentuk instrumen investasi ini tentu menjadi faktor yang sangat penting bagi keberhasilan upaya pemerintah dalam menggalakkan sumber pembiayaan pembangunan dari dalam negeri. Sayangnya, hasil survei Otoritas Jasa Keuangan menunjukkan bahwa sampai saat ini tidak lebih dari 25\% masyarakat memiliki pengetahuan tentang lembaga jasa keuangan, produk dan jasa keuangan, dan memiliki keterampilan untuk menggunakan produk dan jasa keuangan, termasuk pengetahuan fungsional, manfaat, dan risikonya. Untuk itulah program edukasi literasi keuangan ini sangat penting baik bagi masyarakat,khususnya mahasiswa, (sebagai calon investor potensial) maupun bagi pemerintah. 
Untuk berkompetisi dan berbakti kepada masyarakat, mahasiswa STIK Sint. Carolus tentu perlu dipersiapkan untuk memahami peran profesinya di masyarakat sebagai bidan atau perawat. Kemampuan komunikasi wicara dalam konteks kebidanan penting dikuasai dan dipraktikkan mengingat pada dasarnya setiap orang harus hidup secara sosial dan untuk berinteraksi sosial dibutuhkan komunikasi. Menurut Mufti (2015), bercakap, mendengar, menonton, membaca, menulis, berdoa, menilai diri, dan sebagainya merupakan aktivitas komunikasi. Namun kenyataannya, komunikasi tidak selalu mudah walaupun sebagian besar masalah terjadi karena masalah komunikasi. Perlu pemahaman akan kebutuhan komunikasi dan keterampilan dalam komunikasi sehingga dapat tercapai tujuan komunikasi yang diinginkan.

Mahasiswa STIK Sint Carolus sebagai calon bidan yang akan terjun ke masyarakat masih memerlukan pengetahuan dan berbagi pengalaman mengenai masalah komunikasi dan komunikasi yang tepat dalam berinteraksi dengan pasien. Komunikasi yang berorientasi pada pelayanan maksimal berupa penyembuhan pasien atau klien itu dikenal dengan komunikasi terapeutik. Stuart dan Sundeen (1995) menyatakan bahwa komunikasi terapeutik merupakan hubungan interpersonal antara perawat dan klien. Dalam hubungan ini perawat dan klien memperoleh pengalaman belajar bersama dalam rangka memperbaiki pengalaman emosional klien. Berhasil atau tidaknya suatu komunikasi diketahui dari bagaimana mempelajari unsur-unsur yang terkandung dalam proses komunikasi (Nugroho, 2009). Atas dasar itulah, kegiatan pengabdian kepada masyarakat ini bertujuan memberikan edukasi literasi keuangan dan pelatihan komunikasi terapeutik bagi dosen dan mahasiswa kebidanan di STIK Sint Carolus.

\section{MASALAH}

Karena target kegiatan adalah calon perawat yang akan bekerja di rumah sakit dan calon bidan yang memiliki peluang besar untuk berwirausaha membuka klinik kebidanan, berdasarkan kesepakatan bersama pihak STIK Sint Carolus, tim memberikan edukasi keuangan dan pelatihan komunikasi antara pasien dan bidan. Program edukasi ini membekali masyarakat/peserta dengan pengetahuan, pemahaman dan keterampilan pengelolaan keuangan yang lebih baik, sehingga masyarakat menjadi lebih mandiri secara finansial dan pada akhirnya meningkatkan kesejahteraan keluarga. Pengetahuan keuangan adalah suatu kondisi bagi masyarakat yang memiliki pengetahuan dan pemahaman keuangan. Program pendidikan yang akan diselenggarakan bertujuan untuk meningkatkan pengetahuan keuangan masyarakat. Mereka perlu memiliki pengetahuan dan wawasan tentang keuangan, menentukan dan memilih produk dan layanan keuangan yang muncul di masyarakat. Ini sangat berguna untuk masa depan mereka.

Selain itu, komunikasi dengan pasien membutuhkan keterampilan tersendiri yang berbeda dengan keterampilan komunikasi lainnya. Komunikasi yang terjalin bertujuan untuk kesembuhan pasien; oleh sebab itu, masalah ini tidak bisa dianggap sepele mengingat banyak komunikasi tidak efektif karena kurang adanya saling memahami pesan yang disampaikan di antara partisipan. Selain berkomunikasi dengan pasien, mereka juga akan berkomunikasi dengan dokter dan partner-partner yang 
dapat mendukung kesembuhan pasien. Mereka perlu dipersiapkan untuk memiliki keterampilan terapeutik. Perlu dilatihkan bagaimana mengeksplorasi komunikasi verbal dan nonverbal agar lebih peka terhadap makna (implisit dan eksplisit) dari komunikasi tersebut dan memberikan kepuasan pelayanan kepada pasien. Pribadi mengungkap bahwa bidan sebaiknya mampu menunjukkan tiga hal utama, yaitu empati yang diperlihatkan dengan menyentuh emosi pasien, reliability yang ditunjukkan dengan kemampuan memberikan layanan dengan tepat, dan responsif yang dinyatakan dengan kecepatan merespon kebutuhan pasien (Pribadi, 2012). Empati, reliability, dan responsif, yang merupakan bagian dari komunikasi verbal dan nonverbal menjadi penting diasah calon bidan.

Gambar 2. Peta Lokasi STIK Sint Carolus

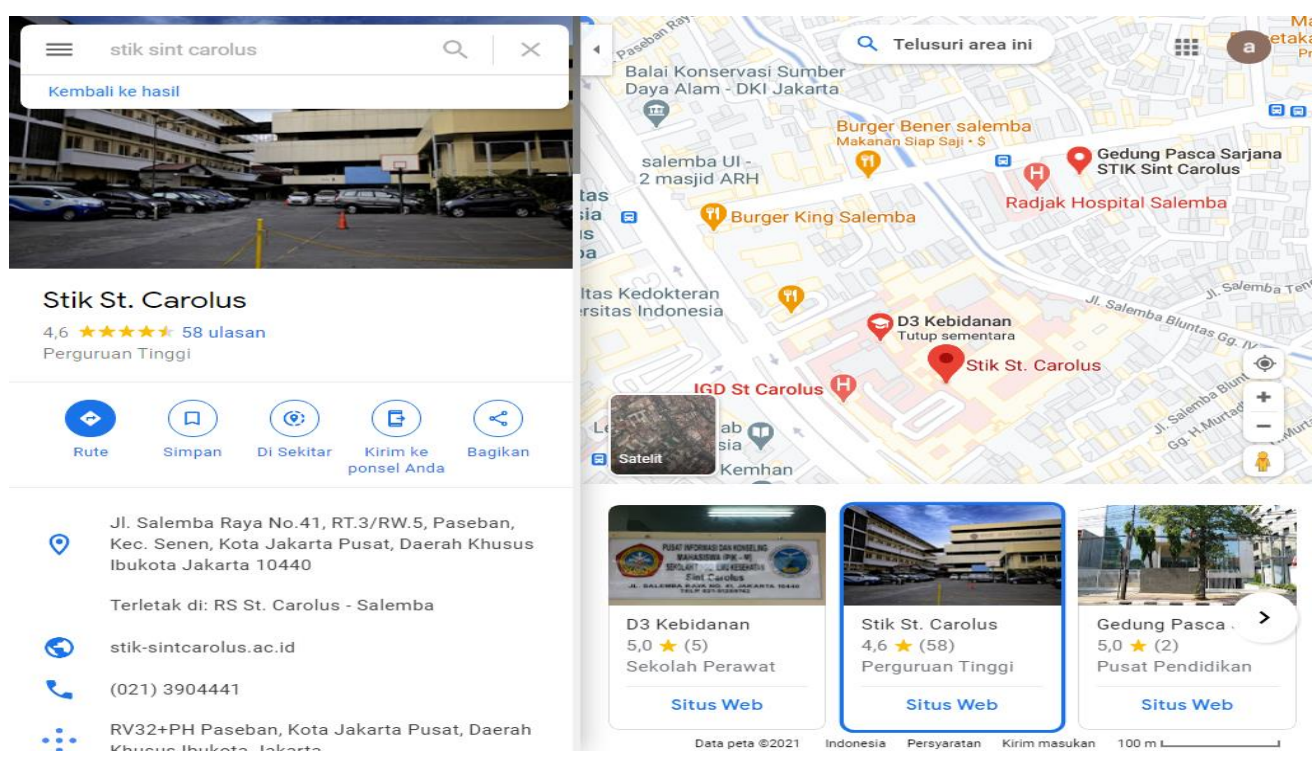

\section{METODE}

Metode pelaksanaan pengabdian kepada masyarakat ini dilaksanakan secara virtual melalui platform Zoom pada awal Desember 2020 dengan peserta dua puluh mahasiswi dan dosen STIK Sint Carolus. Kegiatan pengabdian kepada masyarakat ini menggunakan metode tutorial dan tanya jawab (diskusi). Tahapan kegiatan meliputi persiapan, pelaksanaan, dan evaluasi (Gambar 3).
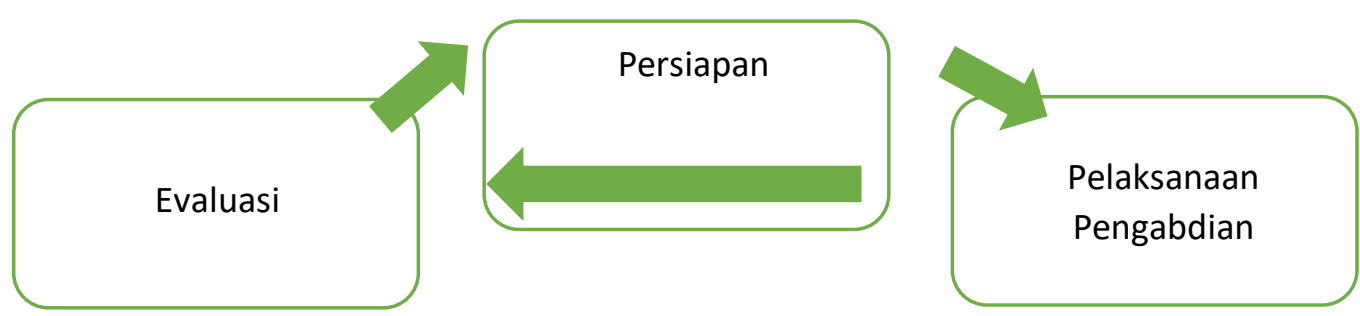

Gambar 3. Tahapan kegiatan 


\section{HASIL DAN PEMBAHASAN}

Tahap Persiapan. Tahap ini dilakukan pada minggu kedua bulan November 2020. Ketua pengabdi melakukan komunikasi dengan Prodi Kebidanan, Ibu Rika, untuk merencanakan tema, target peserta, dan waktu nyang tepat untuk kegiatan pengabdian masyarakat. Dalam penjajakan ini perlu disesuaikan dengan jadwal dari tim kedua pihak dan keadaan pandemi COVID19 yang tidak memungkinkan untuk bertemu. Setelah diskusi baik di pihak internal maupun eksternal, akhirnya tim dapat menentukan target peserta, yaitu para dosen dan mahasiswa dari STIK Sint Carolus. Waktu pengabdian masyarakat ditetapkan pada minggu kedua Desember 2020 setelah mahasiswa selesai Praktik Kerja Lapangan. Langkah selanjutnya, tim menyiapkan proposal untuk diketahui dan disetujui oleh pimpinan fakultas.

Tahap Pelaksanaan. Pada tahap ini tim menyusun modul atau materi yang akan disajikan untuk dibagikan kepada peserta di STIK Sint Carolus. Kemudian tim berkoordinasi dengan tim dari STIK Sint Carolus mengenai tema, tanggal, jumlah peserta, dan dilakukan secara virtual melalui Zoom meeting. Jadwal pelaksanaan diputuskan 11 Desember 2020.

Setelah registrasi, doa pembukaan, sambutan ketua panitia dan ketua prodi STIK Sint Carolus, dimulailah pemaparan materi pertama, yaitu edukasi literasi literasi keuangan (Gambar 4). Dalam materi ini, peserta diperkenalkan berbagai produk atau alat keuangan, termasuk karakteristik, manfaat, dan risikonya, sehingga mereka dapat menentukan dan memilih produk dan layanan keuangan sesuai dengan kebutuhannya.

Selanjutnya, pemaparan kedua, yaitu pelatihan komunikasi terapeutik (Gambar 5). Dalam materi ini, dipaparkan pentingnya komunikasi dalam hubungan pasien-bidan untuk mencapai tujuan bersama, yaitu kesembuhan total pasien. Bidan berkewajiban melayani sesuai dengan kebutuhan pasien sehingga pasien merasakan kepuasan pelayanan (Sutini, Patimah, \& Iriana, 2015). Dalam pelatihan ini juga disampaikan bagaimana komunikasi yang efektif agar pasien terbuka dan nyaman berkomunikasi untuk mengutarakan perasaan, keluhan, riwayat penyakit yang diderita, dan sebagainya yang mendukung observasi dokter dan bidan. Pembelajaran mengenai masalah komunikasi yang umum terjadi dibagikan dalam pelatihan ini. Begitu pula, pentingnya memiliki keterampilan berkomunikasi interpersonal ditekankan karena sudah terbukti dari hasil penelitian bahwa ada pengaruh komunikasi interpersonal dengan kepuasan pelayanan di puskesmas (Sutini, Patimah, \& Iriana, 2015). Setelah paparan, dilanjutkan dengan tanya jawab dan foto bersama (Gambar 6).

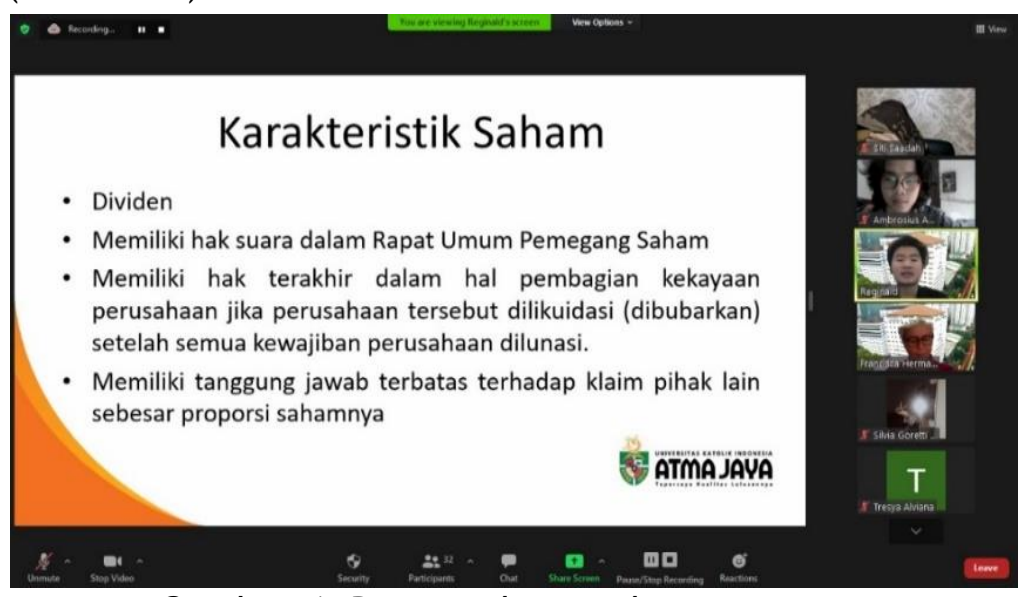

Gambar 4. Paparan literasi keuangan 


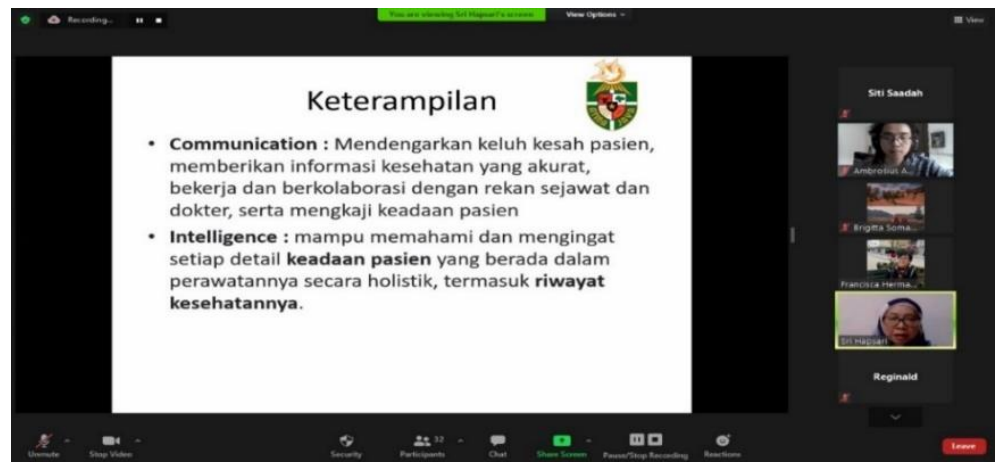

Gambar 5. Paparan komunikasi terapeutik

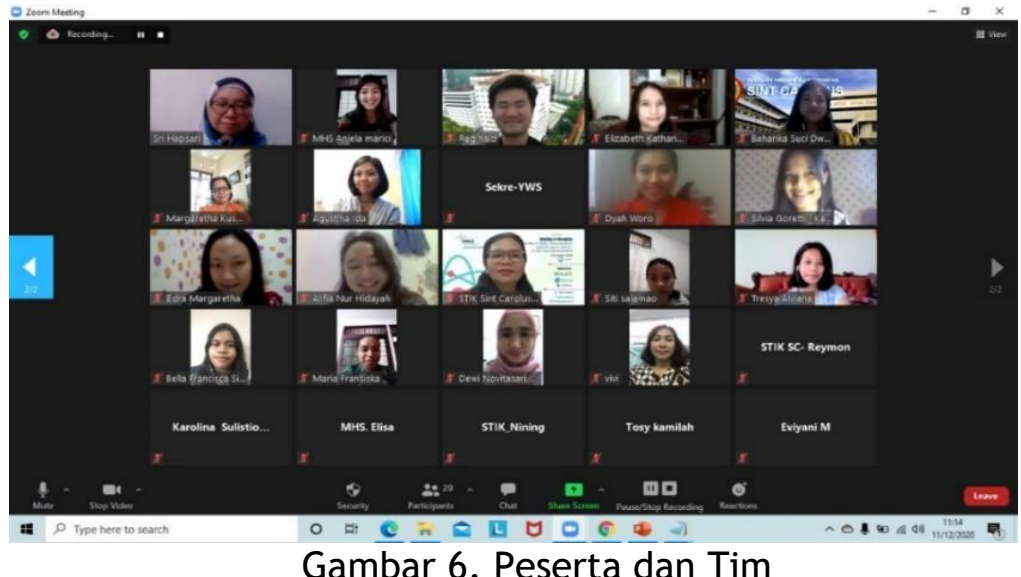

Berdasarkan diskusi dan tanya jawab selama kegiatan pengabdian kepada masyarakat, diperoleh hasil berikut. Pertama, edukasi dan sosialisasi ilmu keuangan bagi dosen dan calon bidan memberikan informasi baru terkait pentingnya pemahaman tentang keuangan dasar. Melihat antusiasme peserta untuk memahami seluk beluk investasi dalam aset keuangan maka diperlukan edukasi literasi keuangan yang lebih mendalam. Hal ini karena pada praktiknya investor/masyarakat umumnya berinvestasi tidak dalam bentuk aset keuangan secara individual, tetapi dalam bentuk portofolio (Bodie, Kane, \& Marcus, 2017). Tujuan pembentukan portofolio ini adalah untuk mengontrol risiko investasi. Oleh karena itu, materi terkait cara pembentukan portofolio menjadi topik lanjutan penting dalam program edukasi literasi keuangan ini. Kedua, peserta sangat antusias untuk mencari informasi detail tentang materi yang diajarkan, khususnya materi yang berkaitan dengan minat reksadana. Peserta termotivasi untuk menggunakan materi yang sudah diberikan untuk kehidupan sehari-hari, terutama bila ingin berinvestasi sejak dini. Hal ini terlihat dari partisipasi aktif peserta dalam proses diskusi dan tanya jawab. Selain itu, peserta mahasiswa aktif bertanya seputar komunikasi yang efektif dengan pasien. Mereka sudah mampu menggambarkan perilaku dan tuturan yang santun yang seharusnya diberikan kepada pasien serta bagaimana menghadapi pasien dengan berbagai sifat dan sikapnya.

Tahap evaluasi. Pada tahap ini peserta secara lisan menyatakan pemahaman mereka yang bertambah mengenai materi. Begitu pula perlunya menjalin kerja sama dalam pengabdian kepada masyarakat di antara kedua belah pihak universitas untuk materi-materi lainnya terkait kesiapan 
mahasiswa untuk terjun ke masyarakat. Pengabdian kepada masyarakat di STIK Sint Carolus berhasil menjadi media kajian ilmu keuangan dan komunikasi terapeutik bagi mahasiswa karena peserta telah memahami materi dan sangat antusias mempelajari ilmu baru.

\section{KESIMPULAN}

Berdasarkan hasil kegiatan pengabdian kepada masyarakat yang telah dilaksanakan, dapat diambil kesimpulan sebagai berikut. Peserta termotivasi untuk menggunakan dan menerapkan materi yang sudah diajarkan, terutama bila ingin berinvestasi sejak dini. Kegiatan ini selain dapat menambah ilmu, juga menambah pengalaman dan menjadi partner diskusi terkait ilmu keuangan dan komunikasi terapeutik. Target peserta program pembelajaran bidan D3 adalah target peserta yang tepat untuk mengikuti program pengabdian ini karena mereka adalah generasi yang akan terjun ke masyarakat untuk mengaplikasikan ilmu kebidanannya.

\section{DAFTAR PUSTAKA}

Bodie, Zvi, Kane, A., \& Marcus, A.J. (2017). Essentials of Investments. McGraw-Hill.

Maryati, S. (2015). Dinamika Pengangguran Terdidik: Tantangan Menuju Bonus Demografi Indonesia. Journal of Economic and Economic Education, 3(2), 124-136. http://ejournal.stkip-pgrisumbar.ac.id/index.php/economica/article/view/249/641.

Mufti, A. Etika Komunikasi. (2015). 2015/12/ etika-komunikasi-dalamperspektif-islam.html, diakses 19 November 2020.

Novi, Y. A. (2017). Pentingya Literasi Keuangan bagi Pengelolaan Keuangan Pribadi. Universitas Negeri Yogyakarta.

Nugroho, A. W. (2009). Komunikasi Interpersonal antara Perawat dan Pasien. Surakarta: FISIPUSM.

Pribadi, T. (2012). Faktor-fakor yang Berhubungan dengan Kepuasan Peserta Jaminan Persalinan (Jampersal) di Wilayah Kerja Puskesmas Batu Brak Kabupaten Lampung Barat Tahun 2021. Jurnal Dunia Kesmas, 1(4), 190-195.

Stolper, O.A. \& Walter, A. (2017). Financial Literacy, Financial Advice, and Financial Behavior. J Bus Econ. DOI 10.1007/s11573-017-0853-9.

Stuart, G. W. \& Sundeen, S. J. (1995). Pocket Guide to Psychiatric Nursing (Third edition). Mosby Year, St.Louis.

Sutini, Patimah,S.,\& Iriana, A. (2015). Pengaruh Komunikasi Interpersonal/Konseling oleh Bidan terhadap Kepuasan Pelayanan Antenatal Care. Jurnal Kesehatan Holistik, 9(1), 47-50. 